\title{
A new species of Nyctimystes (Anura, Hylidae) from Papua New Guinea and comments on poorly-known members of the genus
}

\author{
Stephen J. Richards \\ Vertebrates Department, South Australian Museum, North Terrace, Adelaide, South Australia 5000, Australia. E-mail: \\ Richards.Steve@saugov.sa.gov.au
}

\begin{abstract}
A new species of Nyctimystes (Anura, Hylidae) from Papua New Guinea and comments on poorly-known members of the genus. Nyctimystes kuduki sp. nov. is described from lower-montane rainforest in Southern Highlands Province, Papua New Guinea. It is distinguished from all other members of the genus by its moderately large size (males 58.2-61.0 mm SVL), thick yellow or gold, vertically oriented palpebral venation, lack of dermal heel appendages and presence of vocal slits in adult males. Males call from leaves adjacent to and overhanging fast-flowing streams. The advertisement call is a long series of rasping notes produced at a rate of $0.7-1.1 / \mathrm{s}$, with 9-12 pulses/note and a dominant frequency of 1873-2104 Hz. Brief comments and new data are provided for the poorly-known species $N$. cheesmanae, $N$. montanus and N. semipalmatus.
\end{abstract}

Keywords: Anura, Hylidae, Nyctimystes kuduki sp. nov., Southern Highlands Province, Papua New Guinea, new species, advertisement call.

\section{Introduction}

The genus Nyctimystes is a group of medium to very large tree frogs that are distinguished from other Australopapuan hylid taxa by having a vertical pupil and a distinct palpebral venation (Zweifel 1958). The genus is restricted to New

Received 10 October 2007.

Accepted 21 November 2007.

Distributed December 2007.
Guinea and nearby islands (22 species), northern Australia (1 species), and the Maluku Islands (1 species) (Menzies 2006).

Relationships among New Guinean Nyctimystes are poorly understood. Nyctimystes disruptus Tyler, 1963, N. oktediensis Richards and Johnston, 1993, N. papua (Boulenger, 1897), $N$. trachydermis Zweifel, 1983 and $N$. tyleri Zweifel, 1983 form a distinct and presumably monophyletic group of large, heavybodied species that share two consistent morphological features: 1) sparse palpebral 
venation, and 2) mature males lack a vocal sac (Zweifel 1983, Richards and Johnston 1993). On the basis of its large size and relatively sparse palpebral venation Menzies (2006) associated $N$. narinosus Zweifel, 1958 with this group but it possesses a vocal sac and its relationships are unlikely to be with these species. Nyctimystes species with dense palpebral venation and males possessing a vocal sac include a group of medium-sized frogs (SVL of males 40-60 mm) characterised by predominantly brown coloration, slender build, and advertisement calls consisting of long series of repetitive, rasping notes (Zweifel 1980, Menzies 2006). These include $N$. cheesmanae Tyler, 1964, a species described (as N. montana Parker, 1936) from the Owen Stanley Mountains of eastern New Guinea, and $N$. daymani Zweifel, 1958, described from Mt Dayman in eastern Papua New Guinea.

In this paper I describe a new species of Nyctimystes from Southern Highlands Province, Papua New Guinea that shows some similarities to Nyctimystes cheesmanae but differs from that species in its substantially larger size and different snout shape. I also comment on the status of several poorly known members of the genus.

\section{Material and Methods}

Specimens are deposited in the South Australian Museum, Adelaide (SAMA), and the University of Papua New Guinea Natural Sciences Resource Centre (UPNG) (Appendix I). Voucher specimens were killed in chlorobutanol solution, fixed in 5\% formalin and stored in $70 \%$ ethanol. Samples of liver were extracted from three specimens and stored in $95 \%$ ethanol for future DNA analysis. Measurements (to the nearest $0.1 \mathrm{~mm}$ ) were taken with dial calipers and a stereomicroscope fitted with an ocular micrometer. They are: SVL (snout-vent length), TL (tibia length), HW (head width at angle of jaws, HL (head length from tip of snout to angle of jaws), EYE (horizontal eye diameter), TYM (horizontal tympanum diameter), IN (inter-narial distance), EN (distance between anterior edge of eye and posterior edge of naris), IOD (inter-orbital distance), 3FD (transverse diameter of $3^{\text {rd }}$ finger disc) and 3FP (narrowest width of $3^{\text {rd }}$ finger penultimate phalanx), 4TD and 4TP ( $4^{\text {th }}$ toe disc and penultimate phalanx, as for $3^{\text {rd }}$ finger).

Calls were recorded with a Sony TCM-5000 tape recorder and Sennheiser ME-66 microphone. Air temperature adjacent to calling males was recorded with a Miller \& Weber quick-reading thermometer. Call rate and pulse rate were determined by dividing the total number of calls or pulses minus 1 by the total time from the beginning of the first call or pulse, to the beginning of the final call or pulse. Terminal portions of all calls examined consisted of a series of low-energy, poorlydefined 'sub-pulses' that are probably a result of vocal sac deflation between calls. Measurements of call length and pulse rate presented here exclude these poorly-defined terminal sequences. Thirty calls from two males were analyzed in detail using the AVISOFT SAS-Lab Pro sound analysis program. Coordinates were taken with a GPS using the Datum WGS84. FN $=$ Field number.

\section{Nomenclatural note}

In a recent review of global amphibian systematics, Frost et al. (2006) treated Nyctimystes as a junior synonym of the Australopapuan hylid genus Litoria. Their study demonstrated that the Australian taxon $N$. dayi (Günther, 1897) is more closely related to the Australian Litoria nannotis (Andersson, 1916) than to New Guinean N. pulcher (Wandolleck 1911). However Frost et al. (2006) examined just three specimens of two species of Nyctimystes, and they note (page 131) "The apparent polyphyly of Nyctimystes in our results may be real, although our paucity of sampling prevents us from delimiting the problem precisely.” Because the monophyly of New 
Guinean Nyctimystes with respect to Litoria $+N$. dayi has yet to be disputed I retain use of the name Nyctimystes here.

\section{Species Description}

Nyctimystes kuduki sp. nov.

(Figures 1-6)

Holotype - SAMA R62753 (FN=SJR 2306), adult male collected on Iagifu Ridge, Moro, Southern Highlands Province, Papua New Guinea, $06^{\circ} 23.784^{\prime}$ S, $143^{\circ} 13.339^{\prime}$ E, elevation 930 m a.s.l. on 20 October 2001 by S. Richards.

Paratypes - adult males, UPNG 10047 (FN=SJR 5005), 10048 (FN=SJR 2305), SAMA R62750 (FN=SJR 4932), R62751 (FN=SJR 2301), R62752 (FN=SJR 2302), same data as for holotype except R62750 collected 30 September 1999 and UPNG 10047 collected 13 October 1999; and SAMA R62754 (FN=SJR 8624), torrent at base of Iagifu Ridge, Moro, Southern Highlands Province, Papua New Guinea, 06²1.833'S, 143⒔418'E, elevation $900 \mathrm{~m}$ a.s.l. on 21 November 2004 by J. Hiaso.

Etymology - This species is named for Mr. Max Kuduk, formerly of World Wide Fund for Nature (PNG), in gratitude for his long-term support of the author's research in the Kikori Integrated Conservation and Development Project Area.

Diagnosis - Nyctimystes kuduki sp. nov. can be distinguished from all congeners by a combination of the following characters: (1) moderately large size (males 58.2-62.0 mm SVL), (2) palpebral venation thick, yellow-gold, oriented vertically with few horizontal interconnections; (3) snout nearly acuminate in dorsal aspect; (4) males with vocal slits; (5) heels without prominent tubercles or flaps.

Description of Holotype - Adult male (with vocal slits and calling when collected). Measurements and proportions are presented in Table 1 . Head moderately narrow (HW/SV
0.33 ); snout distinctly pointed in dorsal view (Figure 1), projecting beyond lower jaw in lateral and ventral views; canthus rostralis well defined, nearly straight, loreal region steep, concave; eye to naris distance slightly greater than internarial span (EN/IN 1.13); tympanum extremely small (TYM/SVL 0.04) but well defined, dorsal portion of annulus hidden by short, curved supratympanic fold; eyes large, prominent, clearly visible in ventral view. Pupil vertical when constricted. Iris dark brown in life. Nictitating membrane with thick, verticallyoriented 'veins' of pigmentation with few crossveins (Figure 2). Vomerine teeth on two large, prominent ridges between the choanae. Tongue large, nearly round, indented posteriorly; paired vocal slits extend from behind angle of jaws to half-way between angle of jaws and front of mouth.

Relative lengths of fingers $3>4>2>1$; all fingers with large, prominent terminal discs with deep circum-marginal grooves. Webbing between fingers 3 and 4 extends to base of penultimate subarticular tubercle on both fingers (Figure 3). Inner palmar tubercle prominent, elongate; outer palmar tubercle low, poorly defined; palmar surface with low supernumerary tubercles. Relative lengths of toes $4>3=5>2>1$; all toes with large, prominent terminal discs with deep circum-marginal grooves (Figure 3); toes fully webbed except fourth, where webbing extends to dorsal edge of penultimate subarticular tubercle. Inner metatarsal tubercle prominent, elongate; outer metatarsal tubercle low, indistinct (Figure 3).

Skin very finely granular (shagreened) dorsally; throat and distal portions of limbs smooth ventrally; chest slightly granular, becoming more coarsely granular on belly and upper thighs. A pale, low dermal ridge extends along outer edge of upper arm between elbow and wrist.

Color and pattern of holotype in life: at night dorsum heavily pigmented with tan-brown, relatively uniform on head (dorsally anterior of axillae), becoming more blotchy darker brown 


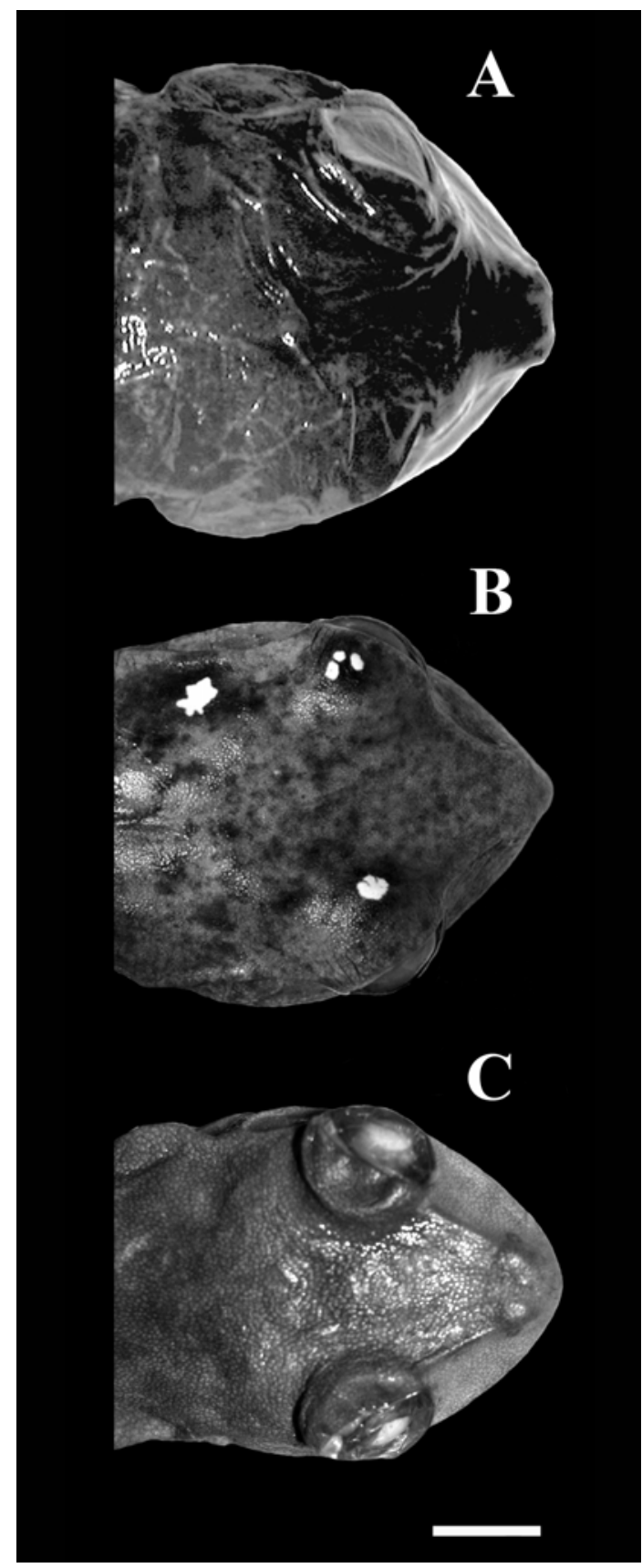

Figure 1 - Dorsal view of head of (A) Nyctimystes montanus holotype (MSNG 29720), (B) $N$. kuduki sp. nov. holotype (SAMA R62753) and (C) N. cheesmanae paratype (BM 1947.2. 24.42). Scale bar $=5 \mathrm{~mm}$.

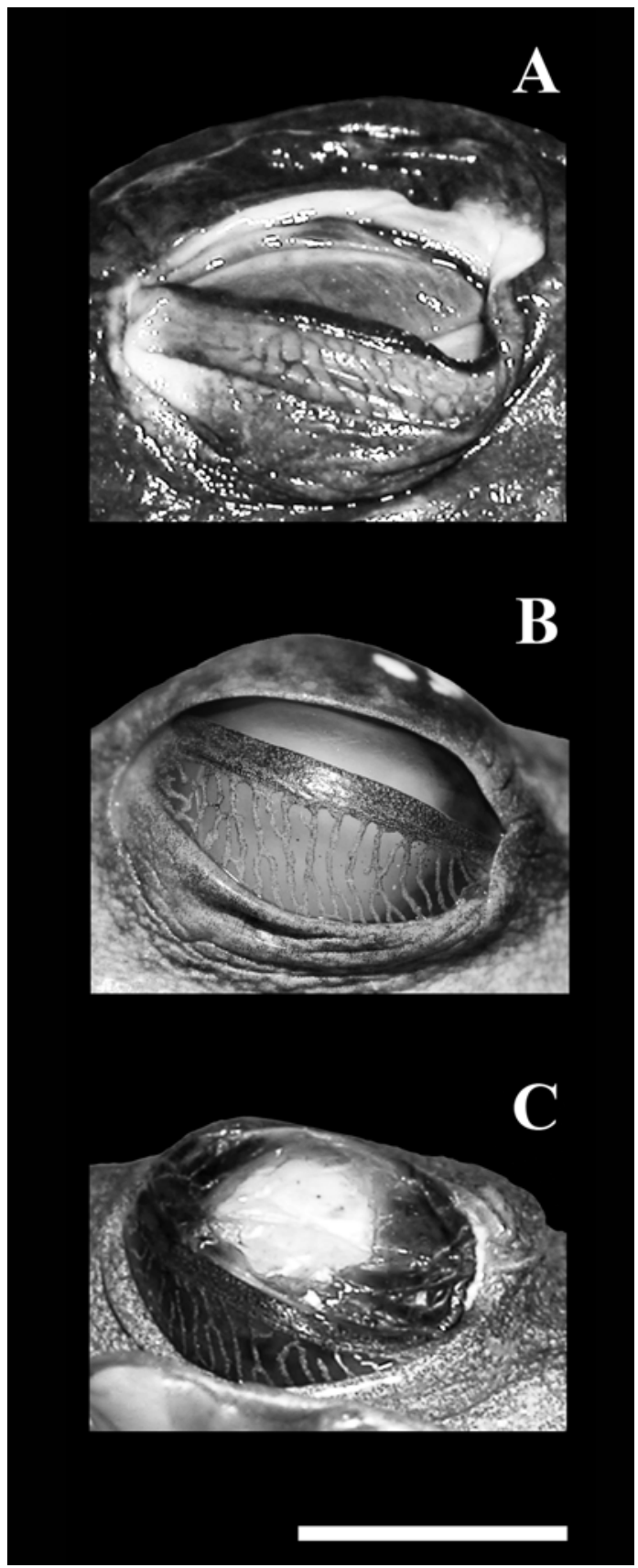

Figure 2 - Palpebral venation of (A) Nyctimystes montanus holotype (MSNG 29720), (B) N. kuduki sp. nov. holotype (SAMA R62753) and (C) $N$. cheesmanae paratype (BM 1947.2.24.42). Scale bar $=5 \mathrm{~mm}$. 


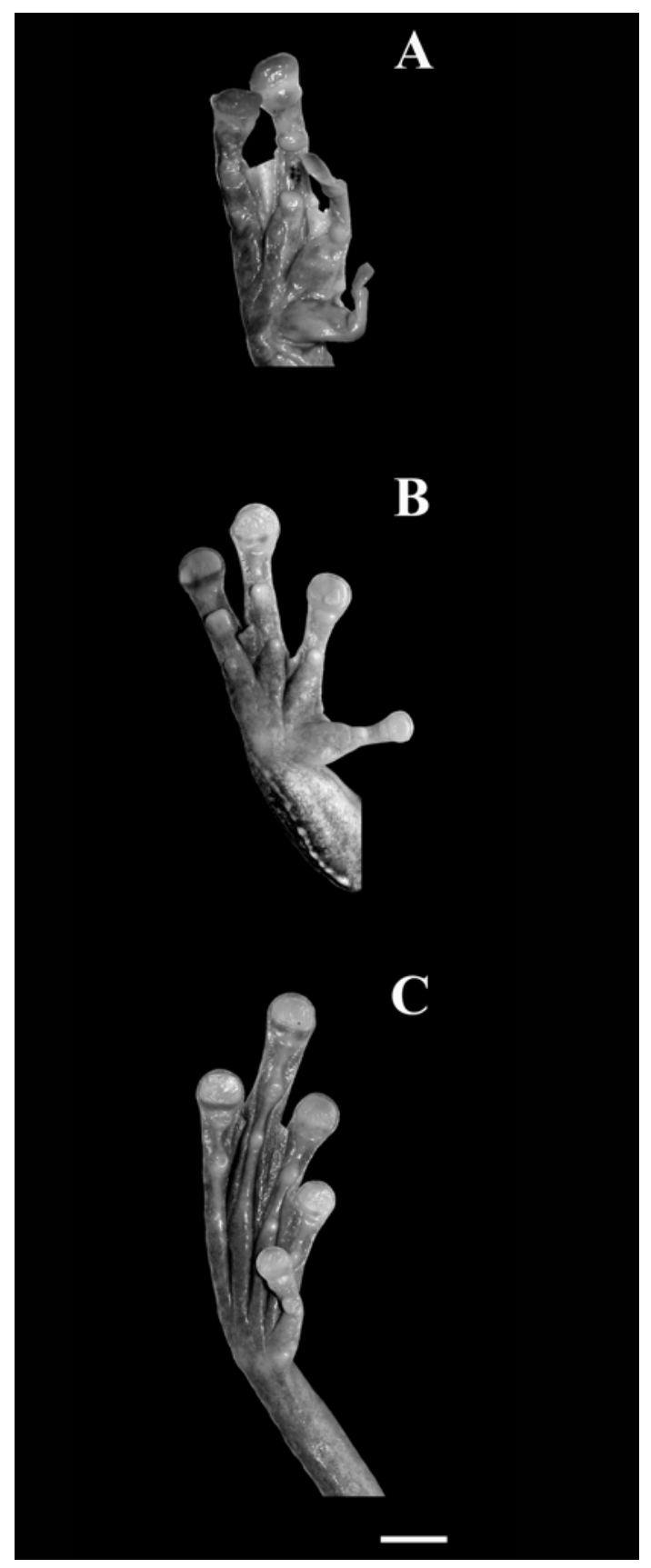

Figure 3 - Palmar view of (A) Nyctimystes montanus holotype (MSNG 29720) and (B) N. kuduki sp. nov. holotype (SAMA R62753), and (C) plantar view of holotype of Nyctimystes kuduki sp. nov. (SAMA R62753) Scale bar $=5 \mathrm{~mm}$. on pale brown posteriorly and on limbs (Figure 4A). Dorsal surfaces of thighs pale yellowbrown with scattered darker brown pigment. Blotches on forearms and tibiae tending to form poorly defined, narrow dark transverse bands. Dorsum with small, scattered off-white spots, and several large, isolated spots 1 ) on dorsal surface of each tibia; 2) on each eyelid (three discrete spots on left eyelid), and behind left eye (Figure 4). Groin yellowish, slightly transluscent; hidden surfaces of thighs pale brown, slightly transluscent; several pale tubercles around vent. Laterally golden yellow; ventrolaterally and ventrally cream with pale yellow tinge. Toes and webbing between toes mottled brown; hand, fingers and finger webbing more yellowish. Finger 1 substantially yellowish dorsally with brown nuptial rugosity. Palpebral venation pale yellow with scattered specks of brown pigment, upper edge of membrane with a band of mottled dark brown and red-brown pigment. During the day overall colors, including yellowish hidden surfaces of limbs, much paler. Dorsum cream-colored with yellowish tinge, faintly mottled with brown. Brown blotches on limbs forming more obvious transverse bars; pale spots on dorsum bright creamy white (Figure 4B). Color in preservative same as above but dorsum now pale tan brown with darker brown mottling; inside of groin transluscent brown; fingers 1-2 cream-colored, with brown pigment specks distally on dorsal surfaces of discs; remaining fingers with denser brown pigmentation. Pale spots on dorsum ivory.

Variation - Measurements and proportions of the paratypes are very similar to the holotype (Table 1). All specimens have a rather angular, protruding snout, although this is less obvious in UPNG 10047 and SAMA R62751. All specimens exhibit faint transverse bars on the limbs and have pale yellow to golden-yellow palpebral venation in life. Palpebral venation always consists of vertical lines with few interconnections and bifurcations. The only 

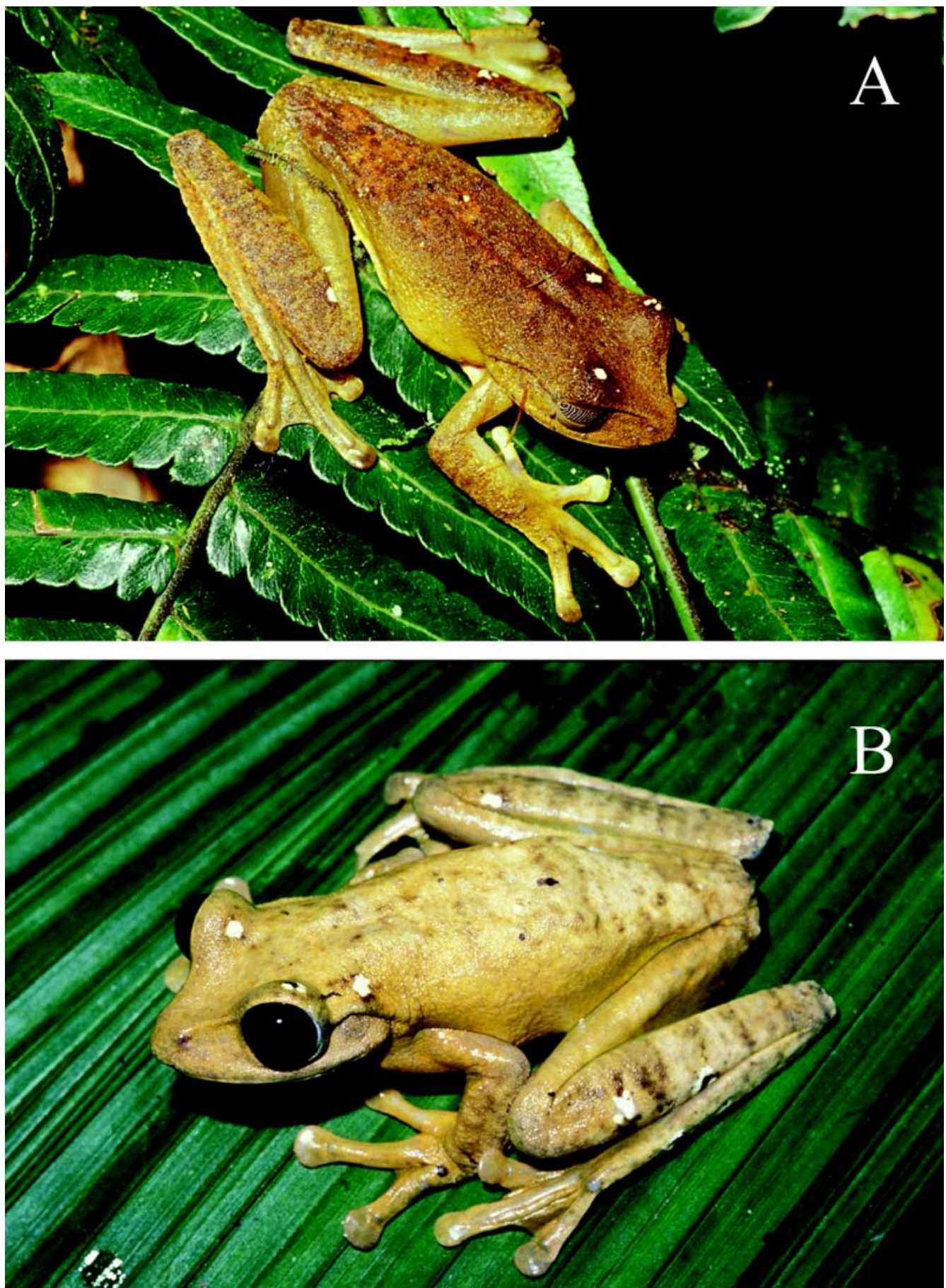

Figure 4 - Holotype of Nyctimystes kuduki sp. nov. (SAMA R62753) in life. (A) Defensive display at night, showing palpebral venation covering eye closest to 'intruder', (B) color pattern during the day. 
exception is SAMA R62752 in which one nictitating membrane has broken and interconnected venation. Venation of the other eye of this specimen is 'typical' of the type series. The major area of variation among the type series is in dorsal color pattern, which varies markedly among the specimens. The ground color of all specimens is brown but the dorsum may be nearly uniformly very dark or very pale brown, or it may be pale brown with darker mottling; there may be small creamy specks or larger spots, or these may be absent. Variation in dorsal patterns of the type series is illustrated in Figure 5.
Advertisement call - The call is a single distinctly pulsed, monotonously repeated rasping note produced in very long series. The end of one 'series' of calls and the beginning of the next one was difficult to determine because, unless disturbed, frogs called near-continuously for very long periods (often more than five minutes) with only slightly longer intervals between calls (= notes) indicative of the end of a call sequence. Forty two calls of a male (SAMA R62750) recorded at $22^{\circ} \mathrm{C}$ lasted a total of 51 seconds $(0.8$ calls $/ \mathrm{s})$ with a minimum inter-call interval of 0.67 seconds and a maximum intercall interval of 2.8 seconds. Values for two other

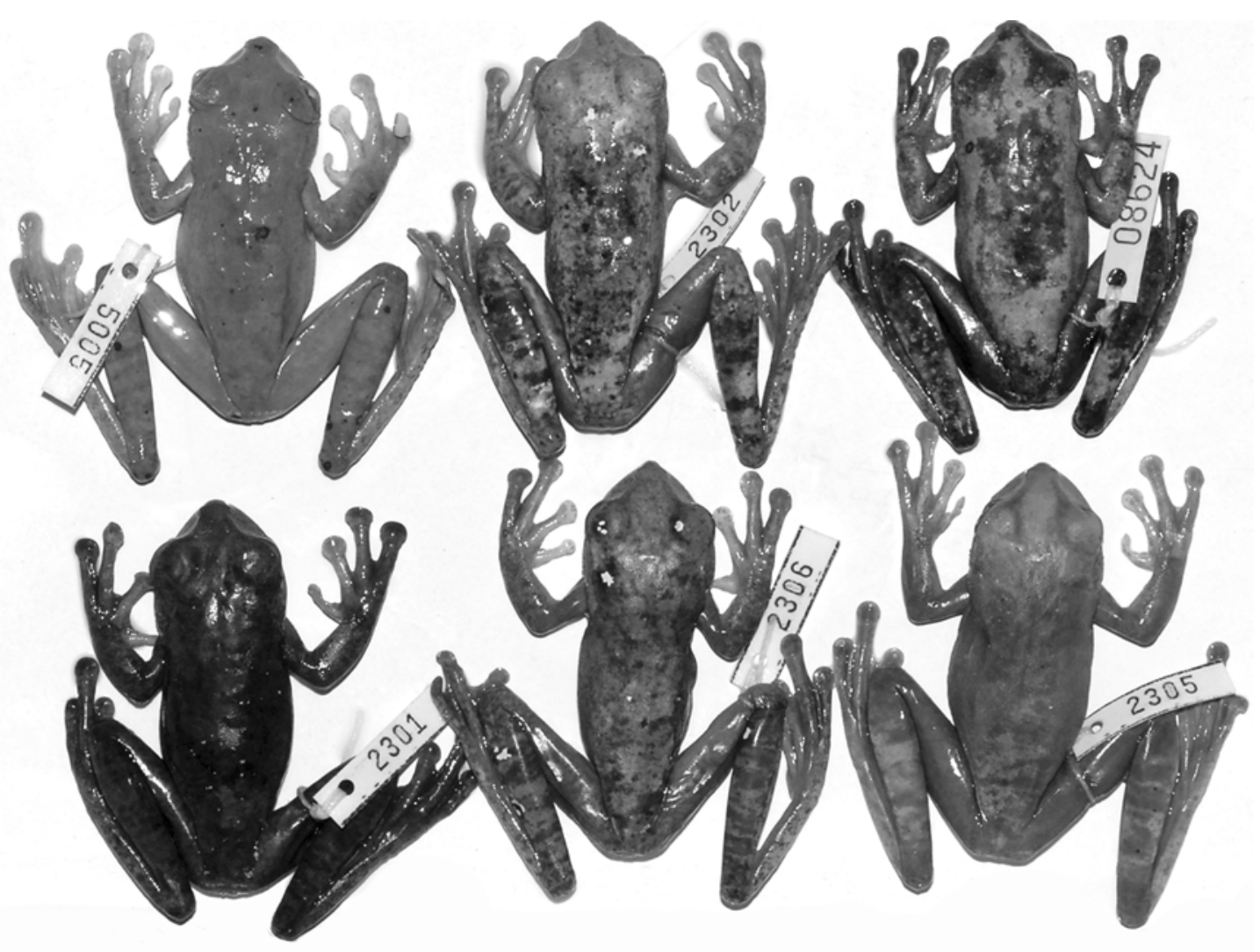

Figure 5 - Type series of Nyctimystes kuduki sp nov. showing variation in dorsal markings. Scale bar $=50 \mathrm{~mm}$. 
Richards

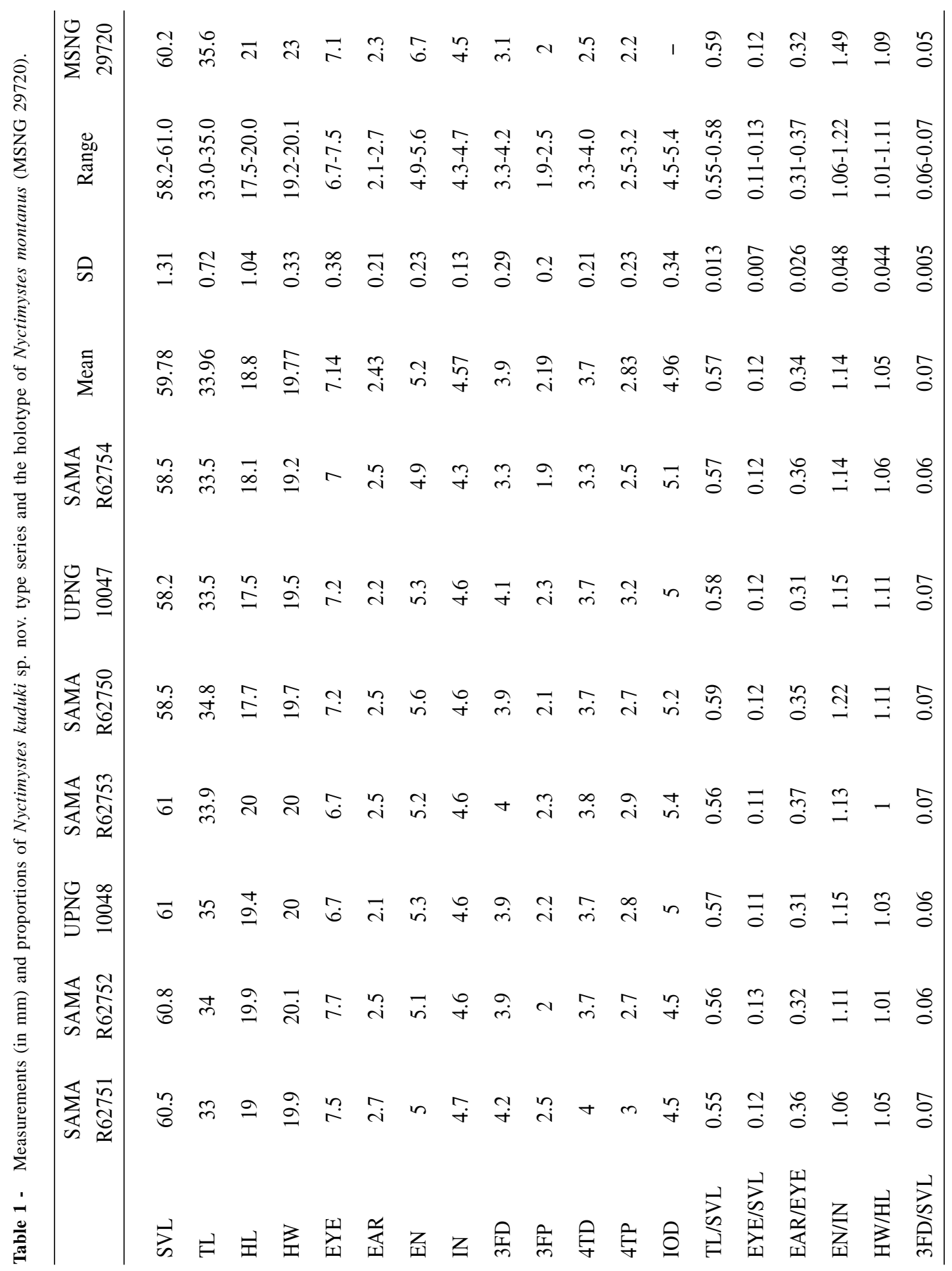






Figure 6 - Advertisement call structure of Nyctimystes kuduki sp. nov. paratype (SAMA R62750) showing wave form (top) and audiospectrogram (bottom) of four consecutive calls recorded at $22^{\circ} \mathrm{C}$.

frogs were 56 calls in 51 seconds $(1.08$ calls/s; maximum inter-call interval $1.46 \mathrm{~s}$, minimum interval $0.61 \mathrm{~s}$ ) at $23^{\circ} \mathrm{C}$ (SAMA R62751), and 34 calls in 51 seconds ( 0.66 calls/s; maximum inter-call interval $3.46 \mathrm{~s}$, minimum interval 0.81 s), also at $23^{\circ} \mathrm{C}$ (SAMA R62752). Structural features of 30 calls from SAMA R62750 and SAMA R62751 are presented in Table 2, and a series of four consecutive calls from within the call sequence of SAMA R62750 is illustrated in Figure 6.

Comparison with other species Nyctimystes kuduki can be distinguished from all members of the $N$. papua group ( $N$. disruptus, $N$. oktediensis, $N$. papua, $N$. trachydermis and N. tyleri; e.g. Zweifel 1983) by possessing a dense, vertically-oriented palpebral venation across the nictitating membrane (vs. sparse, broken venation) and in having adult males with vocal slits (absent in the $N$. papua group; Zweifel 1983). From N. humeralis (Boulenger, 1912) it is distinguished by its much smaller size (male SVL 58-61 mm vs. $100 \mathrm{~mm}$ ), brown (vs. green) dorsum, humerus of male without spinelike projection, and having the palpebral venation oriented vertically with few horizontal connections (vs. palpebral venation a reticulum without obvious orientation). Vertical palpebral venation distinguishes $N$. kuduki from two other species; N. kubori Zweifel, 1958 and N. gularis Parker, 1936 both have 'reticulated' palpebral venation. They are also much smaller than $N$. kuduki (male SVL to 45 and $37 \mathrm{~mm}$ respectively). Nyctimystes kuduki is similar in size to $N$. narinosus (males $\sim 60 \mathrm{~mm} \mathrm{SVL}$ ) but that species has a predominantly horizontal palpebral venation and a dramatic dorsal color pattern of golden blotches on a dark background (Menzies 2006).

Table 2 - Advertisement call characteristics of Nyctimystes kuduki sp. nov. Data are presented as mean \pm SD (range). Air temperature was recorded adjacent to calling males.

\begin{tabular}{lccccccc}
\hline Frog \# & $\mathrm{T}_{\mathrm{a}}\left({ }^{\circ} \mathrm{C}\right)$ & \# of calls & $\begin{array}{c}\text { Call (= note) } \\
\text { length (s) }\end{array}$ & $\begin{array}{c}\text { Call rep. } \\
\text { rate (calls/s) }\end{array}$ & $\begin{array}{c}\text { Pulses } \\
\text { per call }\end{array}$ & $\begin{array}{c}\text { Pulse rep. rate } \\
\text { (pulses/s) }\end{array}$ & $\begin{array}{c}\text { Dominant } \\
\text { frequency (Hz) }\end{array}$ \\
\hline SAMA & 22.0 & 20 & $\begin{array}{c}0.150 \pm 0.006 \\
(0.139-0.160)\end{array}$ & 0.80 & $10.6 \pm 0.76$ & $65.65 \pm 3.84$ & $1946.60 \pm 39.16$ \\
R62750 & & & & $(9-12)$ & $(58.39-73.82)$ & $(1873-2002)$ \\
SAMA & 23.0 & 10 & $0.137 \pm 0.012$ & 1.08 & $11.0 \pm 0.82$ & $75.84 \pm 3.43$ & $2028.30 \pm 66.86$ \\
R62751 & & & $(0.121-0.156)$ & & $(10-12)$ & $(72.00-82.70)$ & $(1889-2109)$ \\
\hline
\end{tabular}


In possessing a palpebral venation of vertical-oblique lines with few cross-sections, and mean EN/IN > 1, N. kuduki most closely resembles some members of Menzies' (2006) 'Group 2' Nyctimystes. It differs from members of that group as follows: From $N$. avocalis Zweifel, 1958, $N$. daymani Zweifel, 1958, $N$. fluviatilis Zweifel, 1958, N. foricula Tyler, 1963, N. obsoletus (Lönnberg ,1900), N. persimilis Zweifel, 1958, N. rueppelli (Boettger, 1895) and $N$. semipalmatus Parker, 1936 it can be distinguished by its much larger size (male SVL > $58 \mathrm{~mm}$ vs. $<45 \mathrm{~mm}$ ). It further differs from avocalis in having males with vocal slits (absent in avocalis); from $N$. fluviatilis in having a much lower eye-naris/inter-naris ratio (maximum EN/IN 1.22 vs. 1.41; Richards and Tjaturadi, unpublished data); from $N$. foricula in its brown coloration (vs. green with a yellow venter); from $N$. obsoletus in lacking a conical heel lappet; from $N$. persimilis in its much higher eye-naris/inter-naris ratio (minimum EN/ IN 1.06 vs. mean of 0.97; Menzies 2006); from $N$. rueppelli by its bold, thick palpebral venation (vs. thin, meandering lines in rueppelli; pers. obs.) and from $N$. semipalmatus by lacking a distinct conical heel lappet.

From the larger species of Nyctimystes (SVL $>50 \mathrm{~mm}$ ) with vertically oriented palpebral venation Nyctimystes kuduki can be distinguished as follows: from $N$. perimetri Zweifel, 1958, a moderately large brown species known only from the Louisiade Archipelago of far-eastern Papua New Guinea by its larger size (male SVL to $61 \mathrm{~mm} v s .52 \mathrm{~mm}$ ) and lack of a heel lappet; from N. granti (Boulenger, 1914) by its smaller size (male SVL of $N$. granti to 80 $\mathrm{mm}$ ) and that species' distinct, vermiculate dorsal pattern (Boulenger 1914); and from the similar-sized (male SVL $60 \mathrm{~mm}$ ) N. pulcher (Wandolleck, 1911) by lacking the very long, prominent heel lappets characteristic of that species. The two species morphologically most similar to $N$. kuduki appear to be $N$. cheesmanae and $N$. montanus (Peters and Doria, 1878). Nyctimystes kuduki can be distinguished from $N$. cheesmanae by its larger size (male cheesmanae $<50 \mathrm{~mm} \mathrm{SVL}$ ) and more angular snout (Figure 1 ), and from $N$. montanus by having an angular (vs. truncate) snout, and parallel vertical palpebral venation with few horizontal connections (vs. numerous horizontal connections) (Figures 1 and 2).

Distribution - Known only from the type locality and one additional stream, both in lower-montane rainforest on Iagifu Ridge near the mining town of Moro, Southern Highlands Province, Papua New Guinea.

Habitat and habits - Nyctimystes kuduki called from between 1.0 and $3.5 \mathrm{~m}$ high on leaves and branches adjacent to two small, clear, fast flowing streams on Iagifu Ridge in the Kikori Integrated Conservation and Development Project area (KICDP). Calling occurred on rainy and dry nights but appeared to be most intense in drier conditions. The two known localities are along a road that connects the mining camp at Moro with mining camps and mining infrastructure at the summit of Iagifu Ridge. Despite heavy vehicular traffic along this road the lower-montane rainforest remains in excellent condition, due largely to strict controls on vegetation disturbance and hunting. Despite intensive survey efforts $N$. kuduki was not encountered around Kopi, Gobe, or Mt Sisa in the KICDP and it may have a limited distribution centered on the Iagifu Ridge/Moro area. Until further data about this species' distribution are available it should be classified as 'Data Deficient' according to the criteria established for the Global Amphibian Assessment.

An interesting behavior exhibited by the holotype prior to capture may shed some light on the function of the palpebral venation in Nyctimystes species. The genus is characterized by having eyes that are exceptionally large and protuberant, and as such the eyes may be obvious to nocturnal predators. When approached in the field the holotype of $N$. 
kuduki raised the nictitating membrane across the eye only on the side of its body being approached. Moving to the opposite side of the frog and approaching from the other side elicited the same response; the frog raised the nictitating membrane across the eye on the side of the approaching 'predator', and lowered it on the eye away from the 'predator', exposing the large dark eye. Six changes in side of approach elicited the same response each time (Figure 4). At least in this species the nictitating membrane appears to play a role in camouflaging the large eye when approached by a potential predator.

\section{Discussion}

Nyctimystes kuduki is a moderately large species that closely resembles $N$. montanus, a species known only from the holotype collected in the Arfak Mountains of far western New Guinea. It also bears some resemblance to $N$. cheesmanae, a species known with certainty only from the type locality in the Owen Stanley Mountains of Papua New Guinea. I have examined the male holotype of $N$. montanus and several male paratypes of $N$. cheesmanae that were collected at Kokoda, about $75 \mathrm{~km}$ to the southeast of the type locality. I have also examined the male specimen referred by Parker (1936) to $N$. semipalmatus, and several paratypes of $N$. daymani. My interpretation of the morphological boundaries of these taxa differs from the recent interpretations of Menzies (2006) and I present my conclusions here.

Nyctimystes cheesmanae Tyler, 1964. This species was described (as N. montana) by Parker (1936) and renamed by Tyler because Parker's name was preoccupied by $N$. montana (Peters and Doria, 1878). In his original description Parker described the male holotype, an adult with a nuptial pad, and commented that the sixteen male paratypes agreed 'admirably' with the holotype. The holotype measures 49 $\mathrm{mm}$ SVL and Parker noted that it has a 'distinctly oblique loreal region'. I have examined three of the paratype series (BM 1947.2.24.42-44) of $N$. cheesmanae. Although these were collected about $75 \mathrm{~km}$ from the type locality, they agree with the holotype in general size, form of the palpebrum, and in having an extremely oblique loreal region. The slope of the loreal region is substantially more exaggerated in the types of $N$. cheesmanae than in any other Nyctimystes that I have examined (Figure 1). The three males I examined are 41.0, 43.5, and $41.6 \mathrm{~mm}$ SVL suggesting that $N$. cheesmanae is a moderately small species with an adult male body length of less than $50 \mathrm{~mm}$. Nyctimystes cheesmanae has caused taxonomic consternation for decades because although moderatesized brown frogs generally resembling the type material are known from widely scattered locations across New Guinea, most of these populations differ sufficiently from the types to prevent confident association with this species (e.g. Zweifel 1980). Collection of topotypic $N$. cheesmanae with associated call and DNA vouchers will be vital for unraveling the taxonomy of these frogs. However I argue that 'true' $N$. cheesmanae is a moderately small species (SVL $<50 \mathrm{~mm}$ ) that can be distinguished from all congeners by its conspicuously oblique loreal region. Most populations referred to this taxon by Menzies (2006) belong to other currently undescribed taxa. The snout shape of a specimen of $N$. cheesmanae (BM 1947.2.24.42) is illustrated in Figure 1 for comparison with $N$. kuduki and to facilitate future identification of populations of this species.

Nyctimystes daymani Zweifel, 1958. The largest of 25 males in the type series of $N$. daymani measures $42 \mathrm{~mm}$ SVL (Zweifel 1958). The type series was collected from Mt Dayman in eastern Papua New Guinea, but Menzies (2006) based his interpretation of this species largely on specimens from Agaun and Baiyer River. I have examined two specimens from the type series of $N$. daymani (AMNH 57081 and 57229), and three specimens from the Baiyer 
River population referred to $N$. daymani by Menzies (2006) (AMNH 80950, 80959 and 80961). The Baiyer River population is not conspecific with $N$. daymani. The two taxa differ markedly in the form of the palpebral venation (thick and bifurcating vertical lines in the Baiyer River population vs. narrow, rarely bifurcating lines in $N$. daymani), and in the relative development of the heel lappet, which is prominent in the Baiyer River specimens and poorly developed in the $N$. daymani types. No name is currently available for the Baiyer River population.

Nyctimystes montanus (Peters and Doria, 1878). The holotype and only known specimen of $N$. montanus (MSNG 29720) is an adult male with distinct nuptial pads. It is rather soft and distorted but is in sufficiently good condition to determine the state of several critical characters. Most importantly, the palpebral venation is visible, and consists of vertical lines with numerous horizontal connections (Figure 2). In this respect it differs from $N$. kuduki, $N$. cheesmanae, and all other Nyctimystes with vertically oriented veins. $N$. montanus also differs from kuduki and cheesmanae in having a snout that is distinctly truncate at the tip. The snout shape, palpebral venation and finger webbing of $N$. montanus are illustrated in Figures 1-3 and a set of critical morphological measurements of the unique specimen are presented in Table 1.

Nyctimystes semipalmatus Parker, 1936. Parker's (1936) description of this species was based on a female holotype measuring $59 \mathrm{~mm}$ SVL. Parker also referred a second specimen, a male measuring $40 \mathrm{~mm}$, to this species. I have examined the male specimen that Parker referred to $N$. semipalmatus. It is a moderately small, slender specimen (SVL $38.8 \mathrm{~mm}$, very close to the measurement provided by Parker) with small conical heel lappets. Although Zweifel (1958) considered $N$. semipalmatus to be a very large species (SVL to $84 \mathrm{~mm}$ in females), he subsequently (Zweifel 1980) concluded that the specimens referred to semipalmatus in his 1958 paper are the same as N. pulcher (Wandolleck 1911), a large species described from the Torricelli Mountains. Based on examination of the holotype of $N$. semipalmatus and of new topotypic material of that species from Kokoda, Zweifel (1980) noted that $N$. semipalmatus is morphologically similar to $N$. cheesmanae. He also reported a useful character for distinguishing between these two species in life: webbing between the digits bright orange in $N$. semipalmatus, vs. grey in $N$. cheesmanae (Zweifel 1980, p. 400).

Zweifel (in litt.) has kindly provided additional information about several topotypic specimens of $N$. semipalmatus: 'SVL of eight adult males (3 Kokoda + 5 Garaina): 43.7-51.3 $\mathrm{mm}$, mean 46.5; two females from Garaina are 49.8 and $53.1 \mathrm{~mm}$. Color notes on specimen number AMNH 74825 (FN=RZ 5970) in life from Kokoda, collected 25 July 1964 (modified slightly from original field notes): Dorsal color brown, varying from dark to light depending on the creature's mood at the moment. Over the brown there is a covering of green flecks so that the brown is not completely dominant. The palpebral reticulum venation consists largely of golden lines, most of them sloping toward the front with very few interconnections. The iris is dark brown, quite a bit darker than the body but not so dark that the vertically oriented pupil cannot be seen. The front and hind limbs show no markings other than the same little green flecks. Ventral surfaces are white with a heavy overlay of orange particularly in the posterior part of the abdomen and underneath the thigh. The webbing of hands and feet is bright orange.” Notes on the two other specimens from Kokoda and additional notes taken at Garaina in 1968 and 1969 confirm the orange webbing.

Menzies (2006) reports that $N$. semipalmatus is a large species (male SVL to $65 \mathrm{~mm}$, female to $84 \mathrm{~mm}$ ). Given the large discrepancy in body size between the specimens discussed by Menzies, and the holotype and topotypic 
material of $N$. semipalmatus it is extremely unlikely that the specimens discussed by Menzies (2006) represent this species.

\section{Acknowledgements}

Type material was collected during a series of surveys that were generously organized and funded by World Wild Fund for Nature (Moro, PNG). I am particularly grateful to Max Kuduk, Ted Mamu, Amos Ona, Daniel Wemp and Dan McCall of WWF for their on-going assistance and support. Rose Singadan and Paulus Kei (University of PNG) provided support in Port Moresby and Barbara Roy (Department of Environment and Conservation) assisted with export permits and with obtaining Provincial approval for the surveys in Southern Highlands Province. Jim Robins (PNG National Research Institute) kindly assisted with my Research Visas. Rose Singadan (UPNG), Mark Hutchinson and Carolyn Kovach (SA Museum), Barry Clarke (Natural History Museum, London), Marinus Hoogmoed and Pim Arntzen (Naturalis, Leiden), Giuliano Doria (Museo Civico di Storia Naturale, Genoa) and Linda Ford, Charles J. Cole and Darrel Frost (American Museum of Natural History) kindly provided access to specimens in their care. Lisa Capon produced the figures and Paul Oliver provided additional assistance at the South Australian Museum. Richard Zweifel provided very useful comments on a draft of this manuscript, and kindly provided unpublished data. Since 2004 my research has been supported by a series of generous grants from
Conservation International. Additional support for this project was received from the Mark Mitchell Research Foundation and the South Australian Museum Board.

\section{References}

Boulenger, G. A. 1914. An annotated list of the batrachians and reptiles collected by the British Ornithologists' Union Expeditions and the Wollaston Expedition in Dutch New Guinea. Transactions of the Zoological Society of London 20: 247-274.

Frost, D. R., T. Grant, J. Faivovich, R. H. Bain, A. Haas, C. F. B. Haddad, R. O. De Sá, A. Channing, M. Wilkinson, S. C. Donnellan, C. J. Raxworthy, J. A. Campbell, B. L. Blotto, P. Moler, R.C. Drewes, R. A. Nussbaum, J. D. Lynch, D. M. Green, and W. C. Wheeler. 2006. The amphibian tree of life. Bulletin of the American Museum of Natural History 297: 1-370.

Menzies, J. I. 2006. The Frogs of New Guinea and the Solomon Islands. Sofia-Moscow. Pensoft. 346 pp.

Parker, H. W. 1936. A collection of reptiles and amphibians from the mountains of British New Guinea. Annals and Magazine of Natural History 17: 66-93.

Richards, S. J. and G. R. Johnston. 1993. A new species of Nyctimystes (Anura: Hylidae) from the Star Mountains, Papua New Guinea. Memoirs of the Queensland Museum 33: 73-76

Zweifel, R. G. 1958. Results of the Archbold Expeditions. No. 78. Frogs of the Papuan hylid genus Nyctimystes. American Museum Novitates 1896: 1-51.

Zweifel, R. G. 1980. Results of the Archbold Expeditions. No. 103. Frogs and lizards from the Huon Peninsula, Papua New Guinea. Bulletin of the American Museum of Natural History 165: 387-434.

Zweifel, R. G. 1983. Two new hylid frogs from Papua New Guinea and a discussion of the Nyctimystes papua species-group. American Museum Novitates 2759: 121. 
Appendix I - Specimens Examined

Abbreviations: $\mathrm{AMNH}=$ American Museum of Natural History, New York; BM = Natural History Museum, London; MSNG = Museo Civico di Storia Naturale, Genoa; SAMA = South Australian Museum, Adelaide; $\mathrm{QM}=$ Queensland Museum, Brisbane. UPNG = Natural Sciences Resource Collection, University of Papua New Guinea, Port Moresby.

Nyctimystes avocalis - AMNH 56486; East slope of Goodenough Island, Milne Bay Province, PNG, $900 \mathrm{~m}$ a.s.l., paratype.

Nyctimystes cheesmanae - BM 1947.2.24. 42-44; Kokoda, Central Province, PNG, 370 m a.s.l., paratypes.

Nyctimystes daymani - AMNH 57081, 57229; North slope of Mt Dayman, Milne Bay Province, $700 \mathrm{~m}$ a.s.l., paratypes.

Nyctimystes fluviatilis - AMNH 49567; Bernhard Camp, Idenburg River, Papua Province, Indonesia, $\sim 50 \mathrm{~m}$ a.s.l., holotype; Uncatalogued series (SJR and B. Tjaturadi collectors), Kwerba, Mamberamo Basin, Papua Province, Indonesia, 50-100 m a.s.l..

Nyctimystes granti - BMNH 1947.2.24.47; Oktakwa River, Mimika, Papua Province, Indonesia, $915 \mathrm{~m}$ a.s.l., holotype.

Nyctimystes gularis - 1947.2.24.29 Mondo, Central Province, PNG, 1500 m a.s.l., holotype; 1947.2.24.30 same data, paratype.

Nyctimystes humeralis - BM 1947.2.23.48; 'Madew', PNG, 600-900 m a.s.l., holotype.

Nyctimystes montanus - MSNG 29720; Hatam, Arfak Mtns, Papua Province, Indonesia, 1800 m a.s.l., holotype.
Nyctimystes narinosus - AMNH 56269, 65859 (plus 3 additional paratypes); Mt Hagen, Western Highlands Province, PNG, $2500 \mathrm{~m}$ a.s.l., paratypes.

Nyctimystes oktediensis - QM J56896; Mt Akrik, Star Mountains, Western Province, PNG, 1625 m a.s.l., holotype; QM J56897-8, SAMA R40771 paratypes, same data as holotype; UPNG 5137-9, Kamfon, Star Mountains, Western Province, PNG, 2200 m a.s.l., paratypes.

Nyctimystes papua - BM 96.10.31.50; Mt Victoria, PNG, lectotype; MCZ 12838; same data as lectotype, paralectotype.

Nyctimystes perimetri - AMNH 60080; West slope of Mt Riu, Sudest (= Tagula) Island, Milne Bay Province, PNG, 250-300 m a.s.l., paratype.

Nyctimystes persimilis - AMNH 56783, 89787, north slope of Mt Dayman, Milne Bay Province, PNG, $1370 \mathrm{~m}$ a.s.l..

Nyctimystes rueppelli - BM 1947.2.23.1114; Halmahera Island, Indonesia, paratypes

Nyctimystes semipalmatus - BM. 1947.2. 24.46; Mt Victoria, PNG, 400 m a.s.l..

Nyctimystes trachydermis - AMNH 8103842; Gapaia Creek, Morobe Province, PNG, 1280 m a.s.l., paratypes.

Nyctimystes tyleri - AMNH 82878; Gapaia Creek, Morobe Province, PNG, 1280 m a.s.l., holotype.

Nyctimystes zweifeli - SAMA R5426; Telefomin, Sandaun Province, PNG, holotype; SAMA R8812-19, same data as holotype, 14001680 m a.s.l., paratypes. 